\title{
On the Current Situation: Normal Violences, Pandemics, Emergencies, Necropolitics, Zombies, and Creepy Treehouses?
}

\author{
Jeremy Hunsinger
}

\section{Introduction}

Universities are meaning-making machines, much like everything else in the knowledge ecologies of late capitalism. They are full of people and things, creating a plurality of meanings and interpretations, and eventually developing knowledge. With that in mind, each university signifies a plurality of purposes to many different public and private interests. These ideas and interests are caught contemporarily in a nihilistic acceleration(Hunsinger 2011a). This acceleration complicates their capacity to be meaningful knowledge systems to many possible participants because the speed erases the possibility of the distributed cognition needed for knowledge(Hunsinger 2009).

The argument put forth in this paper is that amongst the many stories against the transformation during the pandemic, a few are illustrative of a pervasive neoliberal necropolitics arising in universities. This necropolitics is extraordinary violence be perpetrated within and through the university. The structure of this violence and these stories is dialectical, and the resolution in its synthesis is one of capitalistic exploitation.

\section{Contexts}

COVID-19 is our glocal coronavirus pandemic infecting many and killing some. The current coronavirus is an unperfect accident of neoliberalism(Huber 2016; Prudham 2004; Virilio 2007). A vital element of this context is the shift of costs and risks to individuals, preferably future individuals. Another critical aspect of the situation is the transfer of political control and the control of risk and benefit to corporations in what Ulrich Beck called subpolitics (Beck, 1997, 1998, 2000). In this case, questions of hazard around the production and distribution of food enabled the risk of a pandemic virus to manifest as real. The realized virus, which causes the human disease COVID-19 amongst other syndromes, is contagious and seems to be most successful in dense populations such as universities. Significantly, COVID-19 kills some of the people that socially oriented societies such as universities seek to protect. The percentage of deaths varies overall, but in some populations, it can be quite high, and inarguably any death of a community can be traumatic and tragic.

In universities, trauma and tragedy are especially problematic because one of the central 
narratives of the university is hope for the future. Death is ultimately the end of an individual's future, and all hope related to them. Because the management of the university is necessarily now a matter of managing death and the end of hope, it is a de facto necropolitics (Ahmed 2014; Balan 2020; Gournari 2019; Hunsinger 2019).

The framework of the university now requires necropolitics, we must consider the possibility of deaths of students and ourselves, and we have to balance risk against the value of the university, the university degree, and related matters. To teach our students, we must consider endangering them or perhaps killing them unless we engage only online, and then by choosing online, we must have considered the risk of killing them or us. Teaching in the university has become necropolitics, whereas before there was an implicit politics of hopeful futures, now there is the added promise of injury and death. COVID-19 is not the first-time risk like this has presented itself, but it is the largest to date for the contemporary university and its participants.

We should not discount the event's speed in the interaction between COVID-19, nationstates, and universities. While there is speculation about the pandemic's origination at this time of this essay, there was evidence of something happening in January. Canada and the United States reported their first cases in mid-January(Canada 2020; News 2020). The first Canadian Universities closed in the middle of March after the World Health Organization declared COVID-19 a pandemic(Nielsen 2020; Sawyers 2020). Even with the pandemic declared, various constituencies and expert groups conceived the risk of COVID-19 as 'low' it took some time before different models indicated possibly significant effects due to the natures of neoliberal or socialized medical systems.

COVID-19 projects another set of meanings into the university context. COVID-19 fits into a narrative of neoliberal crisis. In any crisis, various interests seek to exploit it. In universities, these interests are internal and external, usually oriented toward reconstructing the university from one of knowledge sharing to knowledge privatization(Etzkowitz and Leydesdorff 1997; Hunsinger 2006; Slaughter and Rhoades 2004). Neoliberalism is the hegemonic ideology of markets seeking to privatize and marketize all things, especially risk(Harvey 2011; Mirowski 2014; Mirowski and Plehwe 2015; Wilson 2018). Universities center on knowledge and knowledge generates risk as risk can obtain from nearly any knowledge. Controlling and privatizing risk is an essential agenda item in neoliberal university governance. However, neoliberalism is under attack itself by thousands of uncomfortable little stories(Lyotard 1989). Neoliberalism is not performing well for the masses. Millions of life-stories are beginning to attest to problems arising from the policies, and the pandemic theoretically brings the number of stories into the billions.

Moreover, the outcomes of neoliberalism, such as austerity and wealth concentration, currently frame our life-stories. In the case of COVID-19, the explicit necropolitics of neoliberalism become apparent with stories questioning the universities' nature, mission, and the university experience. Universities are playing the language games of neoliberal necropolitics by trading the possible deaths of students, faculty, and staff against the goods involved in their brick-andmortar/face-to-face institutionalization (DeLetter 2020; Fain 2020; Flaherty 2020; Lyotard 1984; Quintana 2020).

In the university context, neoliberalism parades as pursuing efficiencies, assessing the excellence of faculty, producing anxiety in the faculty/students, justifying the investment in education and holding the university accountable for their spending(Ball 2012; Berg, Huijbens, and Larsen 2016; Canaan and Shumar 2008). Neoliberal management in universities seems justifiable until one realizes just how much these strategies become the universities' missions more than the pursuit of higher learning. One of the significant impositions of neoliberalism has been the increased number of part-time or adjunct professors. Arguably/nonsensically in the neoliberal university, fewer full-time or tenured faculty will make the university more agile and adaptable to business needs in the future, and less able to resist those needs. However, the increase of precarious labor also increases the administrative workload on full-time faculty and lessens research productivity in relation to teaching productivity, thus changing the relations of knowledge creation significantly within the university system. 
The systemic precarity that part-time professors face in their day to day existence is traumatic. Unionization has helped to resolve some challenges, but without all the protections full-time faculty have, such as tenure or long-term contracts, the university precariat will inarguably absorb an unfair share of the problems of the COVID-19 context.

\section{The University in the Context of Neoliberal Normal Violence}

Universities are mostly modern, physical institutions; they are real places, even if virtual, with real and virtual powers. Those powers perpetuate normal violences and the physical institution houses many forms of normal violence. Normal violence is a seemingly acceptable form of violence because of its everyday occurrence(Cerulo 1998; Dutton 2013). Usually discussed as part of domestic relationships, normal violence is a form of abuse against the other. Generalized, in society, we can see subtle and profound 'normal violence' occurring all around us, be they physical altercations, mental anguish, pervasive anxieties, emotional violences, or otherwise. Normal violence is also discussed in the contexts of terrorism, schooling, general bullying, and in the workplace(Ellwood and Davies 2010; Porras 1994; Saferstein 1994). Conceptually, normal violence entails those violences occurring with such regularity that we accept them. These violences entail an entitlement by someone or something to commit them(Dutton 2006). Normal violences are normalized differently in different ecologies, different cultures. Normal violences are justified as acceptable in different ways; some religions condone some forms of violence, some cultures condone some types, some genders in some cultures have access to some, but not others. Until they are named and resisted, normal violence persists without witness, ignored. Normal violences are rarely repressed through legal enforcement, social enforcement of norms, or similar actions. In fact, in that they are permitted, they are frequently reified as normal. Normal violences seemingly are ignored or tolerated. We ignore them until they cannot be ignored. They are simply normal violences, unexceptional, and impolitic (Apter 2018).

Labeling a violence as normal is not to condone the violence, much like calling it traditional does not condone it. Normal violence is not a good, a right, or a just happening, not that any violence can be good, right, or just. To call it a normal violence is only to say it has become part of our everyday lives and seemingly is accepted by those that live with it.

One of the immediate changes we will face in our landscapes of normal violence is the change from the violences of the physical university to the violences of the emergency remote teaching university. The normal violences of everyday gender, race, class, and other intersectional relations in the face-to-face world of the university are many; unwanted touching, staring, attention, and bullying are amongst them. Online there are many too, and they are now mediated, and the norms of the violences are significantly different, but just as problematic(Benjamin 2019; Phillips 2015; Phillips and Milner 2017; Roberts 2019; Shaw 2014). There is much already researched and known about the differences, but for the sake of this paper, we should recognize there are normal violences online, and there are extraordinary violences online. It is a fact that many of our students and colleagues will be dealing with both online and face-to-face violences in their everyday life. We must recognize the violences and traumas and act appropriately.

Neoliberal necropolitics, as with much of neoliberal politics and its precarities, are forms of normal violence. They perpetuate until witnessed/resisted, and they cause trauma; they categorize and reduce people, dehumanizing them, and worse. Neoliberal necropolitics is not the only ideological origin of normal violence either. Capitalism, racism, classism, fascism, and many other ideological or cultural systems seek to construct and operate systems of normal violence to repress and to 'free' people. The teleologies of the ideologies of normal violence all seem it identify it as reasonable or necessary.

While normal violence is frequently physical(Cerulo 1998), it need not be. It may take many forms. Universities' normal violence is frequently semiological, social, intellectual, conceptual, and occasionally bureaucratic(Hunsinger 2011a, 2019). For instance, universities, academics, and 
their disciplines create hierarchies, divisions, and representations of differences amongst the knowledges and the students who aspire to them. By constructing and signaling differences, they construct social relations where students believe their grades, their major, their sorority/fraternity, and their clubs make them better or worse than other students. Universities become engines against solidarity. The ability to destroy solidarity is significant normal violence celebrated and encouraged to be perfected by neoliberal state apparatus(Evans and Goguen 2019; Harvey 2007, 2011).

The perpetuation of normal violence persists not only against people and their institutions, but also against the practices, the objects of representation, and anything containing meaning. Rapid digital transformation to emergency remote teaching, for instance, is not normal violence but is extraordinary violence becoming normal. While remote teaching seemingly needed to occur to meet bureaucratic necessities, we should not deny its violence against the system in which it exists. Nor should we celebrate the success of the emergency measures, as it would celebrating the explicit failures in which it originated. These failures were failures of foresight, planning, and management. Years of neoliberal mis/management in the form of budgetary cost-cutting, minor economic rewards as motivational constructs for online work, and similar quagmiristic admixtures delayed and confused universities and their faculties eventually leading them to be less than prepared for the eventual pandemic.

Let us be clear here: the faculty and students are the core of the university's mission and general direction. The faculty and students are the existential core of the university; without them, there is no university. Through their labor and commitment to the university, the faculty should provide direction, but the students with those professors provide additional direction. It is their labor and awareness that was distracted by the neoliberal morass of branding, budgeting, and rulemaking, which in part led to the lack of preparedness. The faculty and students managed as well as they did in the pandemic because of their capacities and not to the neoliberal and austerity policies that brought them there.

Faculty labor outside of self-determination and self-governance is exploitative labor; thus, the transition to precarity is exploitative. Exploitation is a form of normal violence. Most new faculty labors are labors brought on by the rise of neoliberalism and its financial regimes. Universities burden faculty with numerable administrative tasks, the so-called administrivia of faculty lives. While teaching, research, and service are normal duties of academia, they too have increased, diversified, and otherwise absorb more time. Like pervasive neoliberalism, COVID-19 has only increased those labors. The emergency transition to online "emergency remote teaching" courses has been an immensely costly exercise, and the costs have been born significantly by faculty and their energies. The challenges of COVID-19 to the nature of faculty time and labor are genuine. Faculty have had to change their relations to students, their university, their colleagues, and their' managers.' All these change the related intellectual and affective labors too. The care and attention one must put into the work of online teaching are profoundly different from face-toface, but the quick transition to online modes of labor has not recognized those facets of faculty labor.

At its heart, the university is still resistant to neoliberal narratives. Universities are bound much more closely with narratives of conviviality, collegia, and communalism. Rooted in each university's contingencies of history, we should recognize the university arose before capitalism(Gray 2012; Perkin 2007). It arose much before neoliberalism, and while some universities have originated new and are designed to be complicit in neoliberalism, not all should be. The university, as imagined and practiced, is a semiosphere signifying differently to different public and private spheres. Inherently though, the university represents three public goods, some of which neoliberal ideologists seek increasingly to privatize. The distinct public goods that universities perform are education, research, and service. The university primarily forms these goods concerning knowledge, its dissemination, and creation, but like all goods, their distribution is tied to questions of equity, justice, and fairness. Universities and individual academics do have duties to these goods and to perpetuate them as part of their nature as university and 
academics(Blunden 1996; Kennedy 1997; Macfarlane 2011; Schall 1988).

Both as narratives and semiosphere, universities and COVID-19 exist in a world of semiological warfare(Eco 1986; Hunsinger 2011). In this world, interests are actively warring with each other for the territories that are our thoughts, our imagination, our attention, and centrally our minds. We live within this warfare of signs, their interpellation, and their interpretation. What those signs mean, what they indicate to you, and what they indicate to others are all matters of contestation or communal closure of contestation. These signs establish as much as any algorithmic or databased system, your reality in the neoliberal order. Being a person that has had COVID-19 or could have COVID-19 is a new false binary construction in this warfare, much like which university, and which degree is a somewhat old part of the warfare, one tied to identity and theoretically status. These semiological systems, their interpretations, and their perpetuations are all bound up in contemporary neoliberalism and the need to symbolically construct exchangeable values packaged into human subjectivities.

\section{University Technocultures}

Universities have their plural subjectivities, and universities co-construct some of those subjectivities through its use of technology. This co-construction is shared by the faculty, the information technology groups, the rest of the administration, the students, and the interuniversity groups in which they participate. University technocultures have also been complicit in the neoliberal mismanagement of the university. The technocultures are part of the academic semiosphere, interacting across the university's shared subjectivities and materialities. The new modalities of technocultures that ally with online learning are embedded within the broader popular and historical understandings of the university and its contexts.

Building the facilities of a virtual university is one piece of this new technoculture, just as the first founding of medieval universities articulated the technics of yet another technoculture tied to the scriptorium, lecture hall, and auditor. While they can throw much light upon each other, the workings of new university technocultures do not exhaust the full range of structural change occurring with informationalization in the global economy and society(Luke 2006)

It is within the informationalization and marketization of the global economy and society that universities have found the pandemic. The structural change they are facing requires them to address the populations in new ways in the current pandemic. The university technocultures also increasingly play a part in the more extensive university presentation, logo, or branding(Holloway and Holloway 2005; Hunsinger 2003). The university technocultures participate in those aspects of identity creation. The technocultural identity comes to embody a representation of the university and participate in the system of semiological warfare.

Universities have both generalizable aspects and specific aspects of their technocultures. These aspects construct relations between universities, but also between universities and their constituents. These constituents imagine the way university varies with the perspective of those technocultures. Technocultures have sought integration into the university's work but have instead become significant parts of the university's work. Faculty, staff, and students spend considerable time and effort learning these technocultures and their technological systems to perform successfully within them and to be able to do their increasingly technologically burdened jobs. While this burden is not new or profoundly different from other informationalized institutions, it does cause specific problems in the university, which is already comprised of distinctively different knowledge ecologies and knowledge cultures as found in academic disciplines, interdisciplinary fields, and transdisciplinary arenas. Most of these disciplines, fields, and arenas have their technocultures based on their knowledge ecologies and cultures. The modes of knowing within the university frequently exist in ecological tension. This tension allows them to be exploited, 
transformed, or concretized in the state of exception of the pandemic.

COVID-19 has provided university technocultures an extraordinary opportunity to centralize their utility in areas where they were used but not necessarily seen as central. To some in the university, the rapid transformation of the centrality of technology is extraordinary violence, and for others, it is a normal violence.

University technoculture is escaping its bounds. Instead of servicing the masters, the technocultures are framing and becoming the masters. The pandemic has canceled the boundary-work, which was keeping technocultures bound(Gieryn 1983). However, the speed of the pandemic intervened, and emergency politics became the justification for the institution's transformation(Honig 2011; Trnka 2020). COVID-19 spread, and university life changed. This change opened a model of technological expansion that cannot be closed. More and more of university life is mediated by information technology and university technocultures. The legitimation of the transformation lacks fundamental justification beyond necropolitical neoliberal risk marketization.

The pandemic also has its normal violences and its necropolitics. We usually accept them as a normal part of the medical apparatus, such as triage, protective clothing, hospitalization, ventilation, etc. In the context of daily life, these too become extraordinary measures, but in the context of a pandemic, they become subtly normalized. This normalization is the process for extending and transforming education, a subtle normalization of extraordinary violence into normal violence. The extraordinary violences possible in online education is becoming normal violences in the age of the pandemic.

\section{Diagnosing the Crisis}

In the state of the exception of emergency politics, COVID-19 allowed the university to ignore and/or break norms and rules(Agamben 2005; Honig 2011; Short 2020). Even in the state of exception, many university administrations showed constraint perhaps in deference to faculty governance structures, or perhaps wisdom. However, in the pandemic emergency, universities could bend and break some norms and rules. They could cause violence to those norms and those who hold those norms. Some norms could not be broken, and it is illustrative to think about why. With the emergency closure of the brick-and-mortar campuses, universities had to condone some rule-breaking behavior in their classes, such as having class remotely or out of the scheduled time. Few if any universities reconsidered what it meant to finish a class or what accounted for the credit that the class represented when finished. The credit was perhaps more important than the class itself. The bureaucratic institution was perhaps more important than the teaching/research institution.

The neoliberal crisis of COVID-19 started long ago and is entangled in the devaluing of life in neoliberal necropolitics. Universities exist contrary to devaluation of life, in favor of increasing the value of life. In contradicting the neoliberal tendency to reduce people to purchasing power, productivities, and consummativities; the university is antithetical to neoliberal bureaucratic management(Baudrillard 1998; Dant 2004; Hunsinger 2015, 2019). Universities take the human being and attempt to make it a complete scientist, scholar, thinker, critic, citizen, or any valuable subject. Faced with the contradictions between the public good of higher learning and the neoliberal need to privatize, marketize, and profit from all goods, the university is caught in a global crisis in which base survival of parts of the population is more important than the goods it provided. This crisis of the university has been constructed over the last fifty years(Mirowski and Plehwe 2015). The history of neoliberalism is the constant attack on public goods and any social programs providing them in favor of the commercialization and privatization of those goods(Harvey 2011; Mirowski 2014). The current crisis is about money; the concentration of wealth, otherwise known as capitalism. Neoliberalism is centrally about capitalism and the fictions of the market. The pandemic was merely a trigger for the crisis that is transforming the 
university; the real crisis is the hegemonic public ideology of neoliberalism. The crisis will not be solved by curing the pandemic either. It must be resisted based on the missions of universities as public goods.

The pandemic caused universities to cease on-campus operations or cease the use of their physical campus. The physical campus, in part, symbolizes the university's value and existence. The shutdown did not end the university's work or even the term. Instead, most universities decided to deliver their teaching online and finish relatively normally. Importantly the 'deliverable' of the 'certification' of the 'course' or 'class' needed to be completed, and the student needed a 'grade' or 'mark' demonstrating their 'completion' of the 'course,' demonstrating their 'knowledge' or 'understanding' of the material they 'learned.' In short, the university's bureaucratic imperative took the highest priority. Students needed to 'complete.' Students, of course, were under pressure to complete their coursework and progress and graduate, as they always are. They migrate on their slow march from the reserve army of capitalism to the army of production, as is a normal violence of capitalism.

As bureaucratic luck would have it, the internet exists and provides a mediated space for interactions using video, audio, text, and other media. Learning has been online via the internet in various parts for well over 40 years, mostly mapping the university's bureaucratic form and classrooms into internet-based media. Online learning has been remarkably successful, but it is profoundly different from the use of the internet entailed by emergency remote teaching. Online learning usually takes months to develop and years to perfect into a quality education by teams of professors and professional developers. Techniques have been practiced and developed over the years to deliver high-quality teaching and interaction. Granted, Mooc providers and similar companies have made models, reduced time, and perhaps found efficiencies to exploit. Emergency remote teaching initially was left in the hands of the professors with little guidance from instructional design. Worldwide, it was primarily a 'do what you can' solution, accelerated by the pandemic. Most professors did quite a bit and delivered an end-of-course experience meeting the imaginations of the students. This exercise in inefficiency satisfied the bureaucratic imperatives of the university. Universities accomplished this exercise quickly, administratively, and with limited democratic input. Students progressed, graduated, and some joined the army of production. The shared governance, collegiality, and community of the university were not spared the violence of the state of exception.

This emergency remote teaching is in/arguably different from online instruction for those attempting to maintain the difference. For those that do not want to preserve the difference, the two are the same. It is now clear to even those that resisted online education; online learning can be pursued, and credentials awarded. We should expect further investments in online learning. The argument will be made on the acclaimed successes of emergency online teaching while ignoring the myriad of failures. We have seen this argument for online learning before, and we have seen the counterarguments too. However, what we have now is the possibility of the emergency to force the change and concretize the extraordinary as normal.

The extraordinary is reifying the bureaucratic imperatives as being above or more important than the public good of higher learning. It is the privatization of the public goods in neoliberalism during the crisis triggered by the pandemic.

\section{Emergency Remote Learning and Creepy Treehouses}

Most faculty have a sense of learning that they build into their learning environments, their syllabi, and their courses. Frequently their understanding of learning is not related to learning as much as it may be related to other mental performances that have come to represent learning(Baudrillard 1994; Remtulla 2008). This problem stems from many faculty's reliance on a sense of learning modeled after their (nostalgic) memory of learning. Within their understanding of learning, many more have the cognitive bias of relying primarily on models of their most 
successful learning. Some may not have reflected on the reasons for success, but a tendency persists in replicating the learning conditions and institutions where the faculty member is comfortable. These are usually traditional settings like classrooms or lecture halls with all the implications of technologies of the self(Foucault 1988). The faculty members have normalized a sense of learning and context, which might not be about learning as much as it is about them and their historical trajectories within their familiar architectures.

One example of this phenomenon is the recognition of learning styles related to modes of perception; arguing that slides help the visual learning, or that the lecture is great for aural learners. Many students and faculty still hold that some people learn better through different perception systems, and we must provide access to different models. This idea of learning styles is widely accepted and generally known to be false according to current research(Antoniuk 2019; Kirschner 2017; Riener and Willingham 2010). However, that it is shown to be false and is generally contested hasn't deterred its acceptance in practice and ideological dissemination. Student's preferences do have implications for learning, but not as learning styles. Still, many professors and university administrators believe that learning styles are real and should be addressed. They create a preference for design based on learning styles, but it is not the only problematic issue in the design of learning environments.

The construction of preferences in learning is not only the professor's preference but also related to the historically built architecture available to them to use. Hopefully, it is also constructed between their students and the broader ecologies of learning. The bricks-and-mortar university physically embodies these learning activities' shared spaces, their ideologies, and praxis, much as businesses represent ideologies and practices in their formal design. Albeit, sometimes people's spaces also embody ideology and praxis outside of and beyond their architectural limits(Bourdieu 1992). It is tough for an instructor to ignore the built-in projector, the computer connection, the whiteboards, much like it is hard for students to ignore the rows of desks, the windows, the constructed front of the room, or other arrangements of the learning space. The technologies of the classroom, as currently imagined, tend to address and reify specific questions of instructional design and learning. They tend to present expertise, tools, and knowledge in an industrial-age disciplinary ideology(Ediger 1987; Foucault 1979; Illich 1971).

Classroom design, like any technological choice, is a set of political decisions(Winner 1980). The chosen technologies exist within an ecology of meaning. The technologies signal things and audiences interpret them. What they interpret has implications for what and how they learn. University technocultures, as such, have an impact on learning, and they are not necessarily aiding higher learning, though parts of the curricula (hidden, null, etc.) are always learned.

Notably, many university technocultures have a clear tendency to reproduce the politics, affordances, and norms of the prior generation's classroom, lab, or seminar environment. Almost all traditional course management systems model the course and its related histories. For instance, in Second Life, where you can be anything and do almost anything, many universities designed buildings where students sat in front of a teacher who stood in front of a simulated whiteboard. Granted, some faculty did otherwise, building simulators of testes, pollination, and schizophrenia(Ando et al. 2011; Beard et al. 2009; Jeffers 2008). While it does take imagination and application to make such experiences for one's students, the learning outcomes were significantly higher in simulations and educational games than in the recreated classrooms. The virtual classrooms were something easy for educational technologists to build and consider within the university technoculture. They were far easier to brand, for instance than a simulation of schizophrenia, which was created by a faculty member.

The faculty and institution's retreat to comfort and familiarity is not necessarily anything other than the response of a set of highly time-pressed and stressed people. They are people bound by their limitations, trajectories, and traditions. However, they continually reproduce choices modeling the classroom and the traditional forms in which they learned. They rarely take risks, and the implicit ideology known as 'best practices' exemplifies their limits. Best practices that arose in the context of a few months of a pandemic are rarely 'best' and likely rarely 'practiced'. 
Granted, the retreat to traditions and norms is the continuity of the disciplines and the performance of the signature pedagogies of those disciplines. It is also why it is tough to teach outside of one's home discipline and part of why it is so challenging to be genuinely interdisciplinary or even transdisciplinary as disciplines are the mental contexts of faculty performance, comfort, and/or familiarity of one's education. Given the differences in pedagogies and disciplines, it is strange that certain paradigms seem to be becoming paradigmatic in the age of emergency remote teaching and remote management of the university. That is the Zoom ${ }^{\odot}$ meeting and Zoom $^{\circ}$ meeting as a classroom.

Zoom $^{\odot}$ has become the killer app of the university's remote administration. Shortly after it introduced into administration, it was introduced as the killer app of online lecturing. Anyone who has participated in enough classrooms has seen classroom zombies. These zombies are students who are completely turned off, checked out, or otherwise no longer participating in the classroom. Similarly, Zoom ${ }^{\odot}$ zombies, sometimes called zoombies, are prevalent both in online Zoom $^{\circ}$ classrooms and in other meetings(Anon 2020; Dovey 2020). The manifestation of this human response as not being 'there' in the face-to-face classroom has been extended to not be

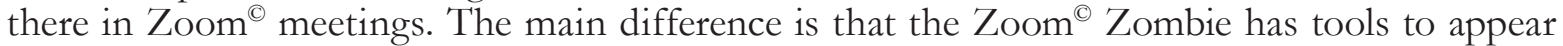
present and participating. Zoom ${ }^{\odot}$ lectures and meetings are full of zombies, and many faculty might not be able to tell. Zombies are coming to embody the technoculture of the Zoom ${ }^{\circ}$ lecture as one would suspect they would, especially those who have studied online learning, or televisual learning have seen. The talking head and even the TED talk lose its efficacy for learning after the user has spent much time coming to terms with the medium. The loss of effectiveness is because much of the pedagogy of the Ted Talk or talking head assume engagement and thought; whereas the slides and video tend to be non-engaging and unthought.

Zombies have always happened in neoliberalism, as people become parts of the productive machine (Brabazon 2016; Lauro 2017; Peck 2010). They are part of the acceptance of our mortality and the death, in part, of our capacity for autonomy. This form of neoliberal zombies is a rejection of wasted time, wasted effort, and wasted outcomes of the practice in which they are performing as zombies. The Zoom ${ }^{\odot}$ zombie cannot 'leave' the meeting, but they must appear to be there. $\mathrm{Zoom}^{\odot}$ zombies are much like many neoliberal zombies who cannot leave their jobs but produce much less than the hours they work. These zombies have the appearance of being at work in a service economy, which has become equated with work. Simulating work has become work(Baudrillard 1994). By using Zoom $^{\odot}$, universities are promoting a certain zombification of our students in the name of what the university imagines and supports as a good learning environment. They are promoting a pacification of the student. They also are training a generation of neoliberal zombies for remote work.

University technocultures and design choices matter immensely. They create zones where learning occurs, but when we abandon those physical zones in times of emergency, we enter into a less determined zone(Hunsinger 2011). The zones are ordered by infrastructures and are zones of semiological warfare. The technological choice of universities and the technological choices of faculty members (if they have that level of academic freedom) are contestable in shared governance.

Shared governance rarely enters technical decisions. Technical decisions by professors and the leaders of their technocultures are informed by their knowledge, their familiarity, and comfort with the field of technological possibility in front of them. One particular metaphorical example of this is the creepy treehouse, which is sort of what $\mathrm{Zoom}^{\odot}$ has become institutionally(Hunsinger 2019; Stein 2008). A creepy treehouse is when a professor uses their position to require their students into a technological choice for teaching or otherwise that the students wouldn't choose, and that choice makes the students feel creepy. The emergency institutionalization of Zoom ${ }^{\odot}$ is very much along these lines. Students did not initially choose $\mathrm{Zoom}^{\circ}$, though they increasingly choose it due to their increasing forced familiarity with it. A more intuitively understood example of this might be something like having students visit a dance club in Second Life that the professor attends regularly. The familiarities of a dance club could be problematic in some ways. The interactions 
possible might be excellent, but it could end up being very uncomfortable for all involved.

Zoom $^{\circ}$ does cause discomfort and worse for some students, as do services such as videobased exam monitoring because the creepiness is a genuine invasion of privacy. Granted, you can block out and use backgrounds and foregrounds to achieve some sort of blocking on $\mathrm{Zoom}^{\odot}$ and other services. Still, the sense that a person has of sharing their space through video lends itself to the feeling of a breach of privacy, and in all practicality, it is. I do not think that I know of any students who would want their professors in their personal or private spaces. Similarly, I would hope professors would not want to be there.

The student's sense of relation is what changes with these interfacialities. The relations of power change, as do the ties of intimacy(Krämer and Haferkamp 2011; Livingstone 2008). Those relations in $\mathrm{Zoom}^{\odot}$ or video monitoring are much different from the classroom. The classroom is a shared space, and for the most part, people consider their computers to be private devices and tend to use them privately. People do use computers for work. They also differentiate living spaces from workspaces and private spaces in both. Students, usually in shared housing or living with parents during the pandemic, do not necessarily have the liberty to define their spaces as workspaces and private spaces. Because of that, they are using video in their spaces will inevitably infringe upon privacy. Not necessarily intentional infringement, but positively a sensible infringement, and it will change students' relations to their learning and their machines(Hunsinger 2019).

In the end, other interfaces are better than $\mathrm{Zoom}^{\circledR}$ for privacy and inclusion. Even Second Life is better, as are the educationally oriented Open Simulators. They can also be a creepy treehouse, but they do allow much more significant privacy and control for students.

The context of time is important to consider here. The emergency accelerated migration from classroom teaching to remote classroom teaching, the use of $\mathrm{Zoom}^{\circ}$, and similar tools were rapid and unmitigated by deep reflection and technological investigation/consideration. We made most of these technological choices not based on best practices, but on an immediate sense of 'fit-to-purpose.' The creepiness starts with the assumptions forcing the decisions and the contingencies and continues by forcing the technological choices as required. The rapid transition and the continued rapid transition are causing, in part, choices to be made, that would and should be made differently, specifically more inclusively. While students are being creeped out, uncomfortable faculty are trying to ameliorate the situation by justifying and legitimizing their actions in an institutional and best practices mode for the university bureaucracy against the students' choices. We are creeping students out, and this is just another stress on top of many that they and we already have.

\section{Signature Pedagogies and Faculty Time in the Normalizing University Technoculture}

Teaching could be generic(Gurung, Chick, and Haynie 2009). Generic teaching would hold that once one learns to teach, and has knowledge to teach, the information can be taught. Some believe teaching to be simple like that, a set of learned skills. Moreover, generic teaching seems to be indicated in part by the generic nature of teaching tools. The classrooms tend to be generic; the online course management system is customizable but generic, the lecture is generic though recently more entertainingly so, and many other parts of the infrastructures of learning are generic. However, while to some, it seems like teaching is generic, each field and subfield has variations on the usage of things and particular ways of teaching certain foundations within it(Chick, Haynie, and Gurung 2012; Gurung et al. 2009). Teaching is very much situated historically, disciplinarily, intersectionally, and otherwise. Teaching in universities is rarely generic, which is why the theorization of artificial intelligence teaching is curious to people who teach(Castro and New 2016; Edwards and Cheok 2018; Goel and Polepeddi 2016; Hunsinger 2019; Saltman 2020).

Fields have a signature pedagogies. For instance, in my doctoral field is Science and Technology Studies (STS), STS tends to be much more constructivist in its approach to knowledge and tends to use more active-learning and student-directed learning in its classrooms than other fields. We 
lead students to concepts through exercises, examples, ethnographies, and narratives in science and technology. Other fields might develop critical and conceptual capacities in different ways and end up with entirely different disciplinary perspectives. Signature pedagogies matter; they matter because they provide context to knowledges and ways of knowing that allow others in your field to recognize your knowledge. Emergency remote teaching erodes the implementation of signature pedagogies.

When faced with the pace of pandemic driven emergency remote teaching, the normalizing influences of the university technocultures will play a significant role in learning. The influence of technocultures increases more in the state of exception as faculty and students are looking to establish new norms. This search for a baseline is especially true in first-year classrooms when students are coming to terms with what it means to have a major and are beginning to develop a disciplinary or interdisciplinary approach to their field/s of study. As students transition to university, the courses they find themselves in do have lasting effects on their education and expectations. The learning of the curricula (overt, social, hidden, null, etc.), which in any class depends significantly on the students, partially has been undermined by the pastiche of the remnants of adequate andragogy into fit-to-purpose technological choices of university technocultures.

Fit-to-purpose choices are not 'good' designs; they are bandages over the wounds of extraordinary violence. Excellent course design takes time, and faculty time is already scarce. If we imagine faculty members working only the hours their contracts pay, which has been between 35 and 42 hours in the places I have worked in my career, there is just not enough time to do their normal jobs. In the pandemic, there is frequently even less time as the mediation of many factors has transformed faculty work lives, such as working at home, family responsibility, technological limitations, etc.

Faculty working conditions vary so significantly that some people will have extensive training and incredible support to accomplish technical tasks, while others have virtually no training or support. This dramatic difference can occur even within most universities as competencies, and the distribution of skills and knowledges varies amongst disciplines, faculties, and in other ways in large universities. In smaller universities and colleges, the battle is always one of the essential resources and accomplishing the tasks within a cost-savings framework. However, bureaucratic cost-saving models usually assume faculty labor and time are 'free' within the system because it is already paid in salaries. These models also assume faculty will put in the work to keep the university afloat, thus putting more pressure on faculty to do more things. Faculty time during the pandemic is an increasingly rare resource as faculty have the many tasks of neoliberal administrivia already. Between resource issues, training issues, and time issues, it should be difficult to assume that faculty can do much more than they already do. Yet in emergency remote teaching, faculty are doing more.

The social and technical infrastructures of teaching provide a normalizing politics and ecological field. The universities' commitment to their infrastructure prevents many faculty members from realizing their models of learning. Faculty want to create the signature pedagogies and andragogies of their disciplines. They want their students to be given the best education from their discipline as they understand it. The technicities and university technocultures do not always allow those andragogies/pedagogies and sometimes actively prevent it. Pandemic signature pedagogies will be mediated by emergency remote teaching in the state of exception. The normal violence of university technocultures imposes an extraordinary violence upon pedagogy and any hopeful attempt at andragogy.

\section{Conclusion}

While this essay used several examples, these examples are illustrative of thousands of stories happening at universities worldwide. The stories demonstrate the university's normal violences 
are changing. The politics are changing, and the pressures on faculty are increasing. The university does feel the pressure, too, as it exists in ecological tension with the faculty.

In the university system, the most substantial relationships in the university are between faculty and students, and it is where the grossest politico-ecological tensions exist. The two groups should be in solidarity, but the pandemic is yet another tool for neoliberal politics to drive them apart. The relationship between those two groups has become mediated by neoliberal necropolitics; their relationship permanently transformed. Universities could return to the position of biopolitics containing the hope for the future. Still, there has been a permanent trauma inscribed into the current relationship. Each of our lives has become part of a series of economic measurements about our death and others. This new relationship has reduced the members of the university by integrating them as calculable risks.

Transformations like this have happened before, with events such as the Virginia Tech Massacre(Agger and Luke 2008). But while those events were local, and the localities resolved them. The current pandemic is glocal, and the distributed ideological shift is harder to resist.

In other parts of the current situation, our lives and workplaces have been molded to the state of exception and emergency politics, and the outcomes of molding are becoming entrenched in university technocultures, institutional politics, and university governance. The system had to change. But it changed to meet the needs of neoliberal necropolitics' bureaucratic imperatives. This change undermines the relationships, research, shared governance, and learning that we seek to develop in university.

Corporations and governments with neoliberal agendas are taking strategic aim at universities in this pandemic. Choices are being constrained, and bureaucratic imperatives are being promoted over higher learning. Money is being made from universities' and individual faculty decisions in ways that will beget new forms of normal violences in the pandemic. People are being exploited. Privacy is being exploited. Learning and research are being exploited. They are being exploited to meet the exigencies of neoliberal necropolitics. Exploitation has become a normal violence. The expansion of this normal violence should be resisted by shared governance. The extraordinary violence of the death of higher learning should be avoided at all costs. 


\section{References}

Agamben, Giorgio. 2005. State of Exception. University of Chicago Press.

Ahmed, Sara. 2014. The Cultural Politics of Emotion. Second edition. Edinburgh: Edinburgh University Press.

Ando, Shuntaro, Sarah Clement, Elizabeth Alexandra Barley, and Graham Thornicroft. 2011. "The Simulation of Hallucinations to Reduce the Stigma of Schizophrenia: A Systematic Review." Schizophrenia Research 133(1):8-16.

Anon. 2020. "Are You a ZOOM ZOMBIE?" ServiceSkills. Retrieved June 14, 2020 (/zoo m-etiquette-are-you-a-zoom-zombie/).

Antoniuk, Andrea. 2019. "Learning Styles: Moving Forward from the Myth." Canadian Journal for New Scholars in Education/ Revue Canadienne Des Jeunes Chercheures et Chercheurs En Éducation 10(2).

Apter, Emily S. 2018. Unexceptional Politics: On Obstruction, Impasse, and the Impolitic. Brooklyn, NY: Verso.

Baker, Paul M. A., Jarice Hanson, and Jeremy Hunsinger. 2013. The Unconnected: Social Justice, Participation, and Engagement in the Information Society (Digital Formations). Peter Lang Publishing Inc.

Balan, Neil. 2020. "Government-in-a-Box, or Understanding Pandemic Measures as Biopolitics | TOPIA: Canadian Journal of Cultural Studies." Topia Covid-19 Essays.

Ball, Stephen J. 2012. "Performativity, Commodification and Commitment: An I-Spy Guide to the Neoliberal University." British Journal of Educational Studies 60(1):17-28.

Baudrillard, Jean. 1998. The Consumer Society: Myths and Structures. London, U.K.: Sage.

Beard, Leslie, Kumanan Wilson, Dante Morra, and Jennifer Keelan. 2009. "A Survey of Health-Related Activities on Second Life." Journal of Medical Internet Research 11(2):e17.
Beck, Ulrich. 1997. "Subpolitics: Ecology and the Disintegration of Institutional Power." Organization \& Environment 10(1):52-65.

Beck, Ulrich. 1998. Democracy Without Enemies. London, U.K.: Polity.

Beck, Ulrich. 2000. What Is Globalization? London, U.K.: Polity.

Benjamin, Ruha. 2019. Race after Technology: Abolitionist Tools for the New Jim Code. Medford, MA: Polity.

Berg, Lawrence D., Edward H. Huijbens, and Henrik Gutzon Larsen. 2016. "Producing Anxiety in the Neoliberal University: Producing Anxiety." The Canadian Geographer / Le Géographe Canadien 60(2):168-80.

Blunden, Ralph. 1996. "Academic Loyalties and Professional Disobedience." Higher Education Research \& Development 15(1):13-28.

Borges, Jorge Luis. 1998. “On the Exactitude of Science. Collected Fictions.” Translated by Andrew Hurley. New York: Penguin 325.

Bourdieu, Pierre. 1992. The Logic of Practice. Stanford University Press.

Brabazon, Tara. 2016. "Don't Fear the Reaper? The Zombie University and Eating Braaaains.” KOME 4(2).

Canaan, Joyce E., and Wesley Shumar. 2008. Structure and Agency in the Neoliberal University. New York: Routledge.

Canada, Public Health Agency of. 2020. "Epidemiological Summary of COVID-19 Cases in Canada." Aem. Retrieved May 28, 2020 (https://health-infobase. canada.ca/covid-19/epidemiological-summary-covid-19-cases.html).

Cerulo, Karen A. 1998. Deciphering Violence: The Cognitive Structure of Right and Wrong. New York: Routledge. 
Chick, Nancy L., Aeron Haynie, and Regan A. R. Gurung, eds. 2012. Exploring More Signature Pedagogies: Approaches to Teaching Disciplinary Habits of Mind. 1st ed. Sterling, Va: Stylus Pub.

Dant, Tim. 2004. Critical Social Theory : Culture, Society and Critique. London, U.K.: Sage.

DeLetter, Emily. 2020. “Citing 'zero Lethal Threat' to Students, Purdue Works to Reopen College for Fall 2020." USA TODAY. Retrieved June 12, 2020 (https://www.usatoday.com/story/ news/education/2020/04/25/coronavirus-college-fall-2020-purdue-university-mitch-daniels/3018469001/).

van Deursen, Alexander JAM, and Jan AGM van Dijk. 2019. “The First-Level Digital Divide Shifts from Inequalities in Physical Access to Inequalities in Material Access." New Media \& Society 21(2):354-75.

Dovey, Seb. 2020. "Wealth Management CTOs Need to Watch out for Zoom Zombies in the Long Term.” IRIS. Retrieved June 14, 2020 (https://www.iris.xyz/fintech/ wealth-management-ctos-need-to-watch-out-for-zoomzombies-in-the-long-term/).

Dutton, Donald G. 2006. Rethinking Domestic Violence. Vancouver: UBC Press.

Dutton, William H. 2013. The Oxford Handbook of Internet Studies. Oxford University Press.

Eco, Umberto. 1986. “Towards a Semiological Guerrilla Warfare." Travels in Hyperreality 135144.

Ellwood, Constance, and Bronwyn Davies. 2010. "Violence and the Moral Order in Contemporary Schooling: A Discursive Analysis." Qualitative Research in Psychology 7(2):85-98.

Evans, Bryan, and Marcel Goguen. 2019. "Policy Paradigms and the Structure of the State Apparatus: Embedding Neoliberalism.” Alternate Routes: A Journal of Critical Social Research 30(2).

Fain, Paul. 2020. "Growing Number of Colleges Announce Intent to Reopen This Fall." Inside Higher Ed. Retrieved June 12, 2020 (https:// www.insidehighered.com/news/2020/04/29/ growing-number-colleges-announce-intent-reopen-fall).
Flaherty, Colleen. 2020. "Plans for Fall Assume Professors Will Be Willing to Teach. Will They?” Inside Higher Ed. Retrieved June 12, 2020 (https://www.insidehighered.com/news/2020/05/04/plans-fall-assumeprofessors-will-be-willing-teach-will-they).

Foucault, Michel. 1988. Technologies of the Self: A Seminar with Michel Foucault. First Edition edition. edited by L. H. Martin and P. H. Hutton. Amherst: Univ of Massachusetts Pr.

Gieryn, T. f. 1983. "Boundary-Work and the Demarcation of Science from Non-Science: Strains and Interests in Professional Ideologies of Scientists." American Sociological Review 48(6):781-95.

Gournari, Panayota. 2019. "The Necropolitics of Austerity: Discursive Constructions and Material Consequences in the Greek Context." Fast Capitalism 13(1).

Gray, Hanna Holborn. 2012. Searching for Utopia: Universities and Their Histories. Berkeley: University of California Press.

Guattari, Felix. 2000. The Three Ecologies. London: Athlone Press.

Gurung, Regan A. R., Nancy L. Chick, and Aeron Haynie, eds. 2009. Exploring Signature Pedagogies: Approaches to Teaching Disciplinary Habits of Mind. 1st ed. Sterling, Va: Stylus Pub.

Harvey, David. 2007. "Neoliberalism as Creative Destruction." The ANNALS of the American Academy of Political and Social Science 610(1):21-44.

Harvey, David. 2011. A Brief History of Neoliberalism. Reprinted. Oxford: Oxford Univ. Press.

Holloway, D. J., and D. A. Holloway. 2005. "University Logos and the Commoditisation of Higher Education." Pp. 34-40 in ANZMAC 2005: Corporate responsibilty.

Honig, Bonnie. 2011. Emergency Politics: Paradox, Law, Democracy. Princeton University Press.

Hunsinger, Jeremy. 2003. “The Academic Logo.” M/C Journal 6(3).

Hunsinger, Jeremy. 2011a. "Against Speed Cosmpolitanism towards the Slow University." Fastcapitalism 10(1). 
Hunsinger, Jeremy. 201 1b. "Interzoning In after Zoning Out on Infrastructure.” M/C Journal 14(5).

Hunsinger, Jeremy. 2015. "Produsing the Hidden: Darknet Consummativities." Produsing Theory in a Digital World2:57-73.

Hunsinger, Jeremy. 2019. “Technology, Democracy, and Hope.” Pp. 1-17 in Handbook of Theory and Research in Cultural Studies and Education, Springer International Handbooks of Education, edited by P. P. Trifonas. Cham: Springer International Publishing.

Jeffers, Debbie. 2008. "Is There a Second Life in Your Future?” Pp. 187-190 in Proceedings of the 36th annual ACM SIGUCCS fall conference: moving mountains, blazing trails, SIGUCCS '08. Portland, OR, USA: Association for Computing Machinery.

Kennedy, Donald. 1997. Academic Duty. Cambridge, Mass: Harvard University Press.

Kirschner, Paul A. 2017. "Stop Propagating the Learning Styles Myth.” Computers \& Education 106:166-71.

Krämer, Nicole C., and Nina Haferkamp. 2011. "Online Self-Presentation: Balancing Privacy Concerns and Impression Construction on Social Networking Sites." Pp. 127-41 in Privacy Online: Perspectives on Privacy and Self-Disclosure in the Social Web, edited by S. Trepte and L. Reinecke. Berlin, Heidelberg: Springer.

Lauro, Sarah Juliet. 2017. Zombie Theory: A Reader.

Livingstone, Sonia. 2008. “Taking Risky Opportunities in Youthful Content Creation: Teenagers' Use of Social Networking Sites for Intimacy, Privacy and SelfExpression." New Media \& Society 10(3):393-411.

Luke, Timothy W. 2006. "Technology and Culture in Online Education: Critical Reflections on a Decade of Distance Learning." In International handbook of virtual learning environments (springer international handbooks of education) (vol. 1 \& 2), edited by J. Weiss, J. Nolan, J. Hunsinger, and P. Trifonas. Springer.

Lyotard, Jean-François. 1989. "Lessons in Paganism." The Lyotard Reader 122-54.

Macfarlane, Bruce. 2011. "Professors as Intellectual Leaders: Formation, Identity and Role." Studies in Higher Education 36(1):57-73.
Mirowski, Philip. 2014. Never Let a Serious Crisis Go to Waste: How Neoliberalism Survived the Financial Meltdown. Paperback ed. London: Verso.

Mirowski, Philip, and Dieter Plehwe. 2015. The Road from Mont Pèlerin: The Making of the Neoliberal Thought Collective, with a New Preface. Harvard University Press.

News, A. B. C. 2020. “Timeline: How Coronavirus Got Started.” ABC News. Retrieved May 28, 2020 (https:// abcnews.go.com/Health/timeline-coronavirus-started/ story id=69435165).

Nielsen, Kevin. 2020. "University of Waterloo, Laurier, Conestoga Suspend on-Campus Classes Due to COVID-19 - Kitchener| Globalnews.Ca." Global News, Digital.

Peck, Jamie. 2010. "Zombie Neoliberalism and the Ambidextrous State." Theoretical Criminology 14(1):104-10.

Perkin, Harold. 2007. "History of Universities." Pp. 159-205 in International Handbook of Higher Education, Springer International Handbooks of Education, edited by J. J. F. Forest and P. G. Altbach. Dordrecht: Springer Netherlands.

Phillips, Whitney. 2015. This Is Why We Can't Have Nice Things: Mapping the Relationship between Online Trolling and Mainstream Culture. Cambridge, Massachusetts: The MIT Press.

Phillips, Whitney, and Ryan M. Milner. 2017. The Ambivalent Internet: Mischief, Oddity, and Antagonism Online. Cambridge, UK ; Malden, MA: Polity.

Porras, Ileana M. 1994. "On Terrorism: Reflections on Violence and the Outlaw." Utah Law Review 1994:119.

Quintana, Chris. 2020. "Colleges Are Emptying Because of Coronavirus. Liberty University Is Inviting Students Back." USA TODAY. Retrieved June 12, 2020 (https://www.usatoday.com/story/ news/education/2020/03/24/coronavirus-liberty-university-reopening-jerry-falwell-jr-donald-trump/2911751001/).

Riener, Cedar, and Daniel Willingham. 2010. "The Myth of Learning Styles." Change: The Magazine of Higher Learning 42(5):32-35. 
Roberts, Sarah T. 2019. Behind the Screen: Content Moderation in the Shadows of Social Media. New Haven: Yale University Press.

Saferstein, Barry. 1994. "Interaction and Ideology at Work: A Case of Constructing and Constraining Television Violence." Social Problems 41(2):316-45.

Sawyers, Katie. 2020. "First Canadian University Closes over COVID-19 Concerns.” Ryersonian.Ca. Retrieved May 28, 2020 (https://ryersonian.ca/first-canadian-university-closes-over-covid-19-concerns/).

Schall, James V. 1988. Another Sort of Learning. San Francisco, CA: Ignatius Press.

Shaw, Adrienne. 2014. "The Internet Is Full of Jerks, Because the World Is Full of Jerks: What Feminist Theory Teaches Us About the Internet." Communication and Critical/Cultural Studies 11(3):273-77.

Short, Jonathan. 2020. "Biopolitical Economies of the COVID-19 Pandemic|TOPIA: Canadian Journal of Cultural Studies."

Stein, Jared. 2008. "Defining Creepy Treehouse." Blog Post].< Http://Flexknowlogy. Learningfield. Org/2008/04/09/Defining-Creepy-Tree-House.

Trnka, Susanna. 2020. "Rethinking States of Emergency." Social Anthropology 1469-8676.12812.

Van Dijk, Jan. 2020. The Digital Divide. Cambridge, UK; Medford, MA: Polity.

Wilson, Julie A. 2018. Neoliberalism. New York: Routledge, Taylor \& Francis Group.

Winner, Langdon. 1980. "Do Artifacts Have Politics. 